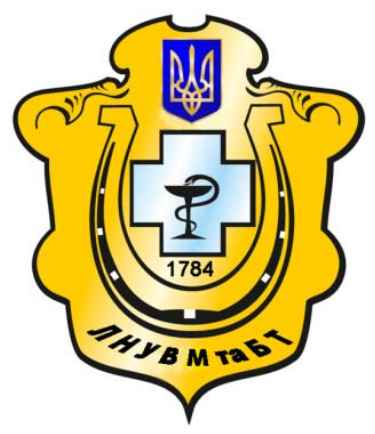

Науковий вісник Львівського національного університету ветеринарної медицини та біотехнологій імені С.3. Гжицького

Scientific Messenger of Lviv National University of Veterinary Medicine and Biotechnologies named after S.Z. Gzhytskyj

doi:10.15421/nvlvet7327

ISSN 2518-7554 print

ISSN 2518-1327 online

$\underline{\text { http://nvlvet.com.ua/ }}$

УДК 636.09:639.3.1.09:616.99

\title{
Білковий склад сироватки крові однорічок білого амура, уражених моногенеями, до та після застосування «Бровармектин-грануляту ${ }^{\text {TM» }}$ i «Авестиму ${ }^{\text {TM }}$ »
}

\author{
О.В. Федорович \\ fedorovychs@ukr.net
}

\begin{abstract}
Львівський національний університет ветеринарної медицини та біотехнологій імені С. 3. Гљицького,
\end{abstract} вул. Пекарська, 50, м. Львів, 79010, Україна

\begin{abstract}
Успішність заходів боротьби з інвазійними хворобами риб залежсть від наявності високоефективних протипаразитарних засобів на фармацевтичному ринку. Тому вчені постійно працюють над розробкою антипаразитарних препаратів для лікування риб, які б мали не лише високу ефективність, менший токсичний вплив на організм та вартість лікувальної обробки, але й сприяли б нормалізації обмінних прочесів. 3 огляду на це метою наших досліджень було вивчити вплив «Бровермектин-грануляту ${ }^{m м » ~ т а ~ « А в е с с т и м у ~}{ }^{m м}$ на білковий склад сироватки крові коропових риб, інвазованих різними ектопаразитами.

Дослідження проведені у садково-рибних господарствах ДП «Рибгосп Галииький» (нині ТОВ «Рибгосп «Бурштинський») Рогатинського району Івано-Франківської області та ФГ «Добротвірський рибзавод» Кам'янко-Бузького району Львівської області, розташованих на теплих водах водойм-охолоджувачів Бурштинської та Добротвірської ТЕС. Для дослідження були відібрані риби з масою тіла 45-47 г.

Встановлено, шо застосування однорічкам білого амура, ураженим збудниками Dactylogyrus lamellatus, Gyrodactylus

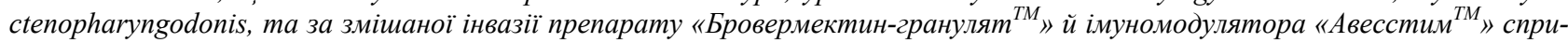
яло активачії білкового обміну в організмі риб, на щуо вказує зростання у їх сироватці крові вмісту загального білка, альбумінів, глобулінів та $\alpha$-глобулінів. Так, за застосування препарату «Бровермектин-гранулят ${ }^{\text {ТМ } в ~ с и р о в а т и і ~ к р о в і ~ у р а ж е н и х ~}$ ектопаразитами риб вміст загального білка, порівняно з контролем, збільшився на 4,23 ( $<<0,001)$, альбумінів - на 2,82 $(P<0,001)$, глобулінів - на 1,41 (P<0,05) ma $\alpha$-глобулінів - на 1,23 г/л $(P<0,01)$. Краму нормалізуючу дію на організм інвазованих риб справляло сукупне застосування цих препаратів: вміст у сироватиі крові загального білка, залежно від виду інвазії, збільшився на 5,22-9,97, альбумінів - на 4,34-8,17, глобулінів - на 0,88-1,45, $\alpha$-глобулінів на - 1,36-2,20 г/л, причому, иі зміни у всіх випадках (виняток - вміст глобуліну у крові риб, уражених гіродактилюсами) були вірогідними (P <0,050,001).
\end{abstract}

Ключові слова: однорічки білого амура, Dactylogyrus lamellatus, Gyrodactylus ctenopharyngodonis, кров, загальний білок, альбуміни, глобуліни, $\alpha$ - , $\beta$ - і $\gamma$-глобуліни, «Бровермектин-гранулят ${ }^{T M}{ }$ «Авесстим $^{T M}$ ».

\section{Белковый состав сыворотки крови однолеток белого амура, пораженных моногенеи, до и после применения «Бровармектин-гранулята ${ }^{\mathrm{TM}} »$ и «Авестима ${ }^{\mathrm{TM}} »$}

\author{
А.В. Федорович \\ fedorovychs@ukr.net
}

Львовский национальный университет ветеринарной медицины и биотехнологий имени С.3. Гәницкого, ул. Пекарская, 50, г. Львов, 79010, Украина

Citation:

Fedorovych, O.V. (2017). Protein composition of blood serum of the same age grass carp affected by monogenea, before and after «Granulated brovermectin» and «Avesstim» use. Scientific Messenger LNUVMBT named after S.Z. Gzhytskyj, 19(73), 131-135. 
Успешность мер борьбы с инвазионными болезнями рыб зависит от наличия высокоэффективных противопаразитарных средств на фармачевтическом рынке. Поэтому ученые постоянно работают над разработкой антипаразитарных препаратов для лечения рыб, которые имели б не только высокую эффективность, меньшее токсическое воздействие на организм и стоимость лечебной обработки, но и способствовали нормализации обменных процессов. Учитывая это, иелью наших исследований было изучить влияние «Бровермектин-гранулята ${ }^{T M}$ 》 $и$ «Авесстима ${ }^{T M}$ »а белковый состав сыворотки крови карповых рыб, инвазированных различныли эктопаразитами. Исследования проведены в садково-рыбных хозяйствах ГП «Рьбхоз Галицкий» (теперь ООО «Рыбхоз «Бурштынский») Рогатинского района Ивано-Франковской области и ФХ «Добротворский рыбзавод» Каменка-Бугского района Львовской области, расположенных на тепльх водах водоемовохладителей Бурштынской и Добротворской ТЭС. Для исследования были отобраны рыбы с массой тела 45-47 ح.

Установлено, что применение одногодкам белого амура, пораженным возбудителями Dactylogyrus lamellatus,

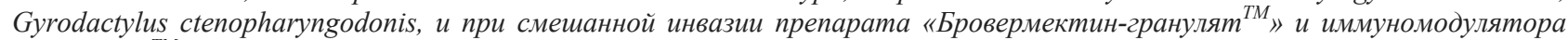
«Авесстим " » способствовало активачии белкового обмена в организме рыб, на что указывает увеличение в их сыворотке крови содержания общего белка, альбуминов, глобулинов и $\alpha$-глобулинов. Так, при применении препарата «Бровермектингранулят ${ }^{T M}$ в сыворотке крови пораженных эктопаразитами рыб содержание общего белка по сравнению с контролем, увеличилось, в зависимости от вида инвазии, на 4,08-4,53 ( $P<0,001)$, альбуминов - на 2,63-3,70 (P<0,001), глобулинов-на 0,83-1,45 (P<0,05-0,01) и а-глобулинов - на 0,77-1,36 г/л $(P<0,05-0,001)$. Лучшие нормализующее действие на организм инвазированных рыб оказывало совокупное применение этих препаратов: содержание в сыворотке крови общего белка, в

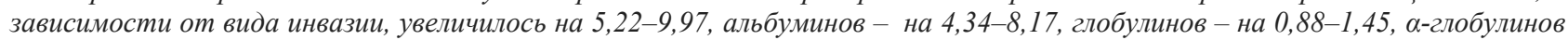
на - 1,36-2,20 г/л, причем, эти изменения во всех случаях (исключение - содержание глобулина в крови рыб, пораженных гиродактилюсами) были достоверными $(P<0,05-0,001)$.

Ключевые слова: одногодки белого амура, Dactylogyrus lamellatus, Gyrodactylus ctenopharyngodonis, кровь, общий бе-

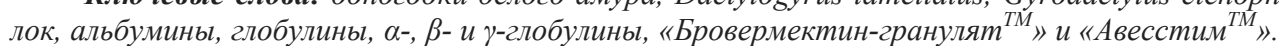

\title{
Protein composition of blood serum of the same age grass carp affected by mon- ogenea, before and after «Granulated brovermectin» and «Avesstim» use
}

\author{
O.V. Fedorovych \\ fedorovychs@ukr.net \\ Lviv national university of veterinary medicine and biotechnologies named after S.Z. Gzhytskyj, \\ Pekarska Str., 50, Lviv, 79010, Ukraine
}

The success of treatment fish with invasive diseases depends on availability of highly efficient antiparasitic drugs in the pharmaceutical market. Therefore, scientists are constantly working to develop anti-parasitic drugs for the treatment of fish that would have not only high efficiency, less toxic to the body and the cost of medical treatment, but also contribute to the normalization of metabolic processes. That is why the purpose of our researches was to study the effect of "Granulated brovermectin» and "Avesstim» on the protein composition of blood serum of carp fish infested by various ectoparasites.

Researches were conducted in garden-fish farms, SOE «Fish farm Halytskyy» (now LLC «Fish farm «Burshtynskyy») Rohatyn raion, Ivano-Frankivsk oblast and FE «Dobrotvir fish factory» Kamianka-Buzka Raion, Lviv oblast, located on the warm waters of cooling ponds of Burshtynsk and Dobrotvir Thermal Power Stations. Fish weighing 45-47 $\mathrm{g}$ were selected for researches.

It was established that the use of «Granulated brovermectin» and immunomodulator "Avesstim» caused activation of protein metabolism in fish body affected by pathogens Dactylogyrus lamellatus, Gyrodactylus ctenopharyngodonis, and mixed infestations and as a result there was indicated the increase of total protein, albumins, globulins and $\alpha$-globulins in their blood serum. Thus, the drug «Granulated brovermectin» in the blood serum of affected by ectoparasites fish total protein content compared with the control, increased to $4.23(P<0.001)$, albumins - to $2.82(P<0.001)$, globulins - to $1.41(P<0.05)$ and $\alpha$-globulins - on 1.23 g/l $(P<0.01)$. Combined use of these drugs showed the best normalizing effect on the infested fish: the content of total protein in blood serum, depending on the type of infestation, increased to 5.22-9.97, albumins - to 4.34-8.17, globulins - 0.88-1.45, $\alpha$-globulins to $1.36-2.20 \mathrm{~g} / \mathrm{l}$, and these changes in all cases (the exception - the quantity of globulins in the blood of fish affected by gyrodactylus) were reliable $(P<0.05-0.001)$.

Key words: the same age grass carp, Dactylogyrus lamellatus, Gyrodactylus ctenopharyngodonis, blood, total protein, albumins, globulins, $\alpha$-, $\beta$ - and $\gamma$-globulins, «Granulated brovermectin», «Avesstim».

\section{Вступ}

Успішність заходів боротьби з інвазійними хворобами риб залежить від наявності високоефективних протипаразитарних засобів на фармацевтичному ринку. Тому вчені постійно працюють над розробкою антипаразитарних препаратів для лікування риб, які б мали не лише високу ефективність, менший токсичний вплив на організм та вартість лікувальної обробки, але й сприяли б нормалізації обмінних процесів (Hrubinko et al., 2010; Osoba et al., 2011; Loboiko et al., 2011).
3 огляду на зазначене, метою наших досліджень було дослідити вплив «Бровермектин-грануляту ${ }^{\mathrm{TM}} »$ та «Авесстиму ${ }^{\mathrm{TM}}$ » на білковий склад сироватки крові коропових риб, інвазованих різними ектопаразитами.

\section{Матеріал і методи досліджень}

Дослідження проведені у садково-рибних господарствах ДП «Рибгосп Галицький» (нині ТОВ «Рибгосп «Бурштинський») Рогатинського району ІваноФранківської області та ФГ «Добротвірський рибзавод» Кам'янко-Бузького району Львівської області, розташованих на теплих водах водойм-охолоджувачів 
Бурштинської та Добротвірської ТЕС. Для дослідження були відібрані однорічки білого амура (з масою тіла 45-47 г), уражені збудниками Dactylogyrus lamellatus, Gyrodactylus ctenopharyngodonis та одночасно обома паразитами. Для вивчення впливу препарату «Бровермектин-гранулят ${ }^{\mathrm{TM}} »$ та імуномодулятора «Авесстим ${ }^{\mathrm{TM}} »$ на білковий склад крові, нами було сформовано по три групи риб по 6 екземплярів у кожній: контрольна - риби, уражені моногенеями, дослідна I - риби, яких лікували антипаразитарним препаратом «Бровермектин-гранулят ${ }^{\mathrm{TM}} »$, дослідна II - риби, яких лікували комплексом препаратів «Бровермектингранулят $^{\mathrm{TM}}$ » та «Авесстим ${ }^{\mathrm{TM}}$ ». Особин кожної групи утримували в окремих акваріумах ємністю 40 дм $^{3}$ iз штучною аерацією за температури $20-22^{\circ} \mathrm{C}$. Їх догляд та годівлю проводили згідно відповідних норм та раціонів. Впродовж усього періоду досліджень проводили спостереження за поведінкою та клінічним станом риб. Переддослідний період акліматизації однорічок товстолобика становив 7 діб.

Лікування інвазованих риб препаратом «Бровермектин-гранулят ${ }^{\text {тм } » ~(у ~ р о з р а х у н к у ~} 60$ мг/кг живої маси риби) та комплексом препаратів «Бровермектингранулят $^{\mathrm{TM}}$ » $\left(60\right.$ мг/кг живої маси риби) $\mathrm{i}$ «Авесстим ${ }^{\mathrm{TM}} »$ (1 мг/кг живої маси риби) проводили два дні поспіль шляхом введення їх перорально за допомогою зонду в передній відділ кишечнику. Перед застосуванням препарати у визначених дозах змішували 31 мл 2\% крохмального клейстеру. Рибам контрольних груп

вводили лише по 1 мл 2\% клейстеру. На 14-у добу після застосування препаратів провели паразитологічний огляд риб та забір крові для досліджень.

Кров відбирали з серця за допомогою одноразового шприца 3 ін'єкційною гепаринізованою голкою. Проби стабілізували гепарином 3 розрахунку 10 од./мл.

Вміст загального білка у сироватці крові риб визначали за біуретовою реакцією (Kondrahin et al., 1985). Метод базується на утворенні у лужному середовищі білками сироватки крові 3 сірчанокислою міддю сполук, зафарбованих у фіолетовий колір. Співвідношення окремих білкових фракцій визначали шляхом електрофоретичного розділення у поліакриламідному гелі (Mauer, 1971).

Одержані дані наукових досліджень обробляли методом варіаційної статистики за Г.Ф. Лакиным (Lakin, 1990) з використанням комп'ютерних програм «Excel» та «Statistica 6.1».

\section{Результати та їх обговорення}

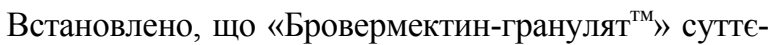
во впливає на білковий обмін в організмі однорічок білого амура, інвазованих збудником Dactylogyrus lamellatus, про що свідчить збільшення вмісту у їх сироватці крові загального білка (табл. 1). У риби, якій вводили зазначений препарат, порівняно 3 контролем цей показник зріс на 4,23 г/л (Р < 0,001) або на 11,7\%.

Таблиия 1

Білковий склад сироватки крові однорічок білого амура, інвазованих Dactylogyrus lamellatus, до та після застосування препаратів, $M \pm \mathbf{m}(\mathrm{n}=6)$

\begin{tabular}{|c|c|c|c|}
\hline \multirow{2}{*}{ Показник } & \multicolumn{3}{|c|}{ Група риб } \\
\hline & контрольна & перша дослідна & друга дослідна \\
\hline Білок загальний, г/л & $36,10 \pm 0,183$ & $40,33 \pm 0,300^{* * *}$ & $41,32 \pm 0,292 * * *$ \\
\hline альбуміни, г/л & $17,53 \pm 0,416$ & $20,35 \pm 0,171^{* * *}$ & $21,87 \pm 0,207 * * *$ \\
\hline глобуліни, г/л & $18,57 \pm 0,267$ & $19,98 \pm 0,327^{* *}$ & $19,45 \pm 0,296^{*}$ \\
\hline альбуміни, \% & $48,55 \pm 0,961$ & $50,46 \pm 0,527$ & $52,93 \pm 0,535^{* *}$ \\
\hline глобуліни, \% & $51,45 \pm 0,961$ & $49,54 \pm 0,527$ & $47,07 \pm 0,535 * *$ \\
\hline$\alpha$-глобуліни, г/л & $7,47 \pm 0,226$ & $8,70 \pm 0,172 * *$ & $8,83 \pm 0,088^{* * *}$ \\
\hline$\beta$-глобуліни, г/л & $6,92 \pm 0,264$ & $7,03 \pm 0,125$ & $6,72 \pm 0,148$ \\
\hline$\gamma$-глобуліни, г/л & $4,18 \pm 0,312$ & $4,25 \pm 0,380$ & $3,90 \pm 0,262$ \\
\hline$\alpha$-глобуліни, \% & $40,19 \pm 0,741$ & $43,56 \pm 0,933^{*}$ & $45,46 \pm 0,861 * * *$ \\
\hline$\beta$-глобуліни, \% & $37,23 \pm 1,148$ & $35,27 \pm 1,124$ & $34,53 \pm 0,536$ \\
\hline$\gamma$-глобуліни, \% & $22,58 \pm 1,771$ & $21,17 \pm 1,535$ & $20,01 \pm 1,144$ \\
\hline А/Г коефіцієнт & $0,95 \pm 0,037$ & $1,02 \pm 0,021$ & $1,13 \pm 0,025^{* *}$ \\
\hline
\end{tabular}

Примітка. * $-\mathrm{P}<0,05, * *-\mathrm{P}<0,01, * * *-\mathrm{P}<0,001-$ порівняно 3 контрольною групою.

У риб першої дослідної групи відмічалося також збільшення у сироватці крові вмісту альбумінів та глобулінів - відповідно на 2,82 (P < 0,001) та 1,41 г/л $(\mathrm{P}<0,05)$. Спостерігалися зміни і у глобулінових фракціях білка, проте достовірними вони були лише за вмістом у сироватці крові $\alpha$-глобулінів. У риб першої дослідної групи порівняно з контролем цей показник зріс на 1,23 г/л (Р <0,01) або на 3,37\% (P < 0,05). Після лікування «Бровермектин-гранулятом ${ }^{\mathrm{TM}} »$ вміст у сироватці крові однорічок білого амура $\beta$ - i $\gamma$ глобулінів зменшився відповідно на 1,96 та 1,41\%.

На покращення фракційного складу білка у сироватці крові риб після застосування препарату вказує також альбуміново-глобуліновий коефіцієнт, який у риби першої дослідної групи порівняно з контрольною збільшився на 0,07 .

Більш ефективний вплив на обмінні процеси в організмі уражених риб мало сумісне використання «Бровермектин-грануляту ${ }^{\mathrm{TM}} » 3$ «Авесстимом ${ }^{\mathrm{TM}} »$. Так, у риб другої дослідної групи порівняно з контрольною вміст у сироватці крові загального білка, альбумінів, глобулінів та $\alpha$-глобулінів вірогідно збільшився відповідно на 5,22 (Р < 0,001); 4,34 (P<0,001); 0,88 $(\mathrm{P}<0,05)$ та 1,36 г/л $(\mathrm{P}<0,001)$, а вміст $\beta$ - і $\gamma$ глобулінів незначно зменшився - відповідно на 0,20 та 0,28 г/л. У відносних величинах вміст $\alpha$-глобулінів збільшився на 5,27 (Р < 0,001), а $\beta$ - і $\gamma$-глобулінів зменшився на 2,70 і 2,57\%. Альбуміново-глобулінове 
відношення в однорічок білого амура другої дослідної групи було найвищим $(1,13)$. У них цей показник порівняно з рибою контрольної групи зріс на 0,18 , а порівняно $з$ особинами першої дослідної групи - на 0,11 при $\mathrm{P}<0,01$ в обох випадках.

Між рибою, яку лікували одним препаратом та комплексом препаратів також спостерігалися відмінності за показниками білкового складу сироватки крові, проте вони були вірогідними лише за вмістом загального білка, альбумінів та альбуміново-глобуліновим відношенням і становили відповідно 0,99 г/л $(\mathrm{P}<0,05)$, 1,52 г/л $(\mathrm{P}<0,001)$ та $0,11(\mathrm{P}<0,01)$.

Подібні зміни вмісту загального білка та його фракцій після застосування «Бровермектин-гранулят ${ }^{\mathrm{TM}}$ » були відмічені також у сироватці крові білого амура, ураженого Gyrodactylus ctenopharyngodonis (табл. 2). Вміст у їх сироватці крові загального білка збільшився на 4,08 (Р < 0,001), альбумінів - на 2,63 (Р < 0,001) та глобулінів - на 1,45 г/л $(\mathrm{P}<0,05)$. Було відмічено також достовірне зростання $\alpha$-глобулінової фракції на 1,36 г/л (P $<0,001)$ і зовсім незначне збільшення $\beta$ та $\gamma$-глобулінової фракцій. У той же час відносний вміст альбумінів у сироватці крові лікованої риби порівняно 3 контрольною групою збільшився на 1,89, $\alpha$-глобулінів - на 4,14\%, а глобулінів, $\beta$ - і $\gamma$-глобулінів - зменшився відповідно на 1,89; 1,49 і 2,65\%. Альбуміново-глобулінове відношення у риб першої дослідної групи порівняно з контрольною зросло на 0,07 .

Таблиия 2

Білковий склад сироватки крові однорічок білого амура, інвазованих Gyrodactylus ctenopharyngodonis, до та після застосування препаратів, $M \pm \mathbf{m}(\mathrm{n}=6)$

\begin{tabular}{|c|c|c|c|}
\hline \multirow{2}{*}{ Показник } & \multicolumn{3}{|c|}{ Група риб } \\
\cline { 2 - 4 } & контрольна & перша дослідна & друга дослідна \\
\hline Білок загальний, г/л & $34,30 \pm 0,181$ & $38,38 \pm 0,325^{* * *}$ & $40,90 \pm 0,412^{* * *}$ \\
\hline альбуміни, г/л & $16,13 \pm 0,376$ & $18,76 \pm 0,269^{* * *}$ & $21,57 \pm 0,257^{* * *}$ \\
\hline глобуліни, г/л & $18,17 \pm 0,327$ & $19,62 \pm 0,508^{*}$ & $19,33 \pm 0,550$ \\
\hline альбуміни, \% & $47,03 \pm 0,995$ & $48,92 \pm 0,955$ & $52,76 \pm 0,934^{* *}$ \\
\hline глобуліни, \% & $52,97 \pm 0,995$ & $51,08 \pm 0,955$ & $47,24 \pm 0,934^{* *}$ \\
\hline$\alpha$-глобуліни, г/л & $6,99 \pm 0,152$ & $8,35 \pm 0,205^{* * *}$ & $8,62 \pm 0,186^{* * *}$ \\
\hline$\beta$-глобуліни, г/л & $6,83 \pm 0,105$ & $7,10 \pm 0,224$ & $6,80 \pm 0,223$ \\
\hline$\gamma$-глобуліни, г/л & $4,35 \pm 0,540$ & $4,17 \pm 0,553$ & $3,92 \pm 0,554$ \\
\hline$\alpha$-глобуліни, \% & $38,63 \pm 1,383$ & $42,77 \pm 1,996$ & $44,76 \pm 1,789^{*}$ \\
\hline$\beta$-глобуліни, \% & $37,70 \pm 1,203$ & $36,21 \pm 0,885$ & $35,22 \pm 1,123$ \\
\hline$\gamma$-глобуліни, \% & $23,67 \pm 2,557$ & $21,02 \pm 2,301$ & $20,02 \pm 2,302$ \\
\hline А/Г коефіціснт & $0,89 \pm 0,036$ & $0,96 \pm 0,036$ & $1,12 \pm 0,041^{* *}$ \\
\hline
\end{tabular}

За комплексного застосування досліджуваних препаратів у однорічок білого амура білковий обмін значно покращився. Вміст загального білка у їх сироватці крові порівняно з інвазованою рибою збільшився на 6,60, альбумінів - на 5,44, глобулінів - на 1,16 та $\alpha$ глобулінів - на 1,63 г/л при Р <0,001 у всіх випадках (виняток - вміст глобулінів). Майже незмінною залишалася $\beta$-глобулінова фракція білка, а $\gamma$-глобулінова зменшилася на 0,43 г/л. Спостерігалося вірогідне (P < 0,05; Р < 0,001) збільшення відносного вмісту альбумінів та $\alpha$-глобулінів - на 5,73 та $6,13 \%$ відповідно та невірогідне зменшення $\beta$ - і $\gamma$-глобулінів - на 2,48 i $3,65 \%$. Достовірним було і збільшення альбуміновоглобулінового коефіцієнту - на 0,23 (P<0,01).
За досліджуваними показниками білкового складу сироватки крові риби першої та другої дослідної груп також відрізнялися між собою, однак, достовірна різниця була виявлена лише за вмістом загального білка, альбумінів та альбуміново-глобуліновим коефіцієнтом. Вона становила відповідно 2,52 г/л $(\mathrm{P}<0,001) ; 2,81$ г/л $(\mathrm{P}<0,001)$ та 0,16 $(\mathrm{P}<0,05)$.

Застосування «Бровермектин-грануляту ${ }^{\mathrm{TM}} »$ та імуномодулятора «Авесстим ${ }^{\mathrm{TM}}$ » мало також стимулюючий вплив на обмінні процеси у організмі однорічок білого амура, інвазованого одночасно Dactylogyrus lamellatus i Gyrodactylus ctenopharyngodonis (табл. 3).

Таблиця 3

Білковий склад сироватки крові однорічок білого амура, інвазованих Dactylogyrus lamellatus i Gyrodactylus ctenopharyngodonis, до та після застосування препаратів, $\mathbf{M} \pm \mathbf{m}(\mathbf{n}=6)$

\begin{tabular}{|c|c|c|c|}
\hline \multirow{2}{*}{ Показник } & \multicolumn{3}{|c|}{ Група риб } \\
\hline & контрольна & перша дослідна & друга дослідна \\
\hline Білок загальний, г/л & $30,50 \pm 0,202$ & $35,03 \pm 0,313 * * *$ & $40,47 \pm 0,289 * * *$ \\
\hline альбуміни, г/л & $13,33 \pm 0,311$ & $17,03 \pm 0,650 * * *$ & $21,50 \pm 0,655 * * *$ \\
\hline глобуліни, г/л & $17,17 \pm 0,203$ & $18,00 \pm 0,706^{*}$ & $18,97 \pm 0,764^{*}$ \\
\hline альбуміни, \% & $43,70 \pm 0,819$ & $48,63 \pm 1,857$ & $53,15 \pm 1,703 * *$ \\
\hline глобуліни, \% & $56,30 \pm 0,819$ & $51,37 \pm 1,857$ & $46,85 \pm 1,703 * *$ \\
\hline$\alpha$-глобуліни, г/л & $6,40 \pm 0,214$ & $7,17 \pm 0,266^{*}$ & $8,60 \pm 0,286^{* * *}$ \\
\hline$\beta$-глобуліни, г/л & $6,77 \pm 0,164$ & $6,80 \pm 0,185$ & $6,73 \pm 0,233$ \\
\hline$\gamma$-глобуліни, г/л & $3,98 \pm 0,511$ & $4,03 \pm 0,905$ & $3,63 \pm 0,928$ \\
\hline$\alpha$-глобуліни, \% & $37,34 \pm 1,560$ & $40,21 \pm 2,595$ & $45,79 \pm 2,800^{*}$ \\
\hline$\beta$-глобуліни, \% & $39,57 \pm 1,282$ & $37,93 \pm 1,356$ & $36,61 \pm 1,247$ \\
\hline$\gamma$-глобуліни, \% & $23,09 \pm 2,745$ & $21,86 \pm 3,827$ & $18,60 \pm 3,823$ \\
\hline А/Г коефіцієнт & $0,78 \pm 0,026$ & $0,96 \pm 0,064^{*}$ & $1,15 \pm 0,071 * * *$ \\
\hline
\end{tabular}


Результати наших досліджень свідчать, що після застосування «Бровермектин-грануляту ${ }^{\mathrm{TM}}$ » у сироватці крові риб порівняно з контролем відмічалося збільшення вмісту загального білка - на 4,53 г/л (Р < 0,001). Достовірні зміни були виявлені і за вмістом альбумінів, глобулінів та $\alpha$-глобулінів, а $\beta$ - та $\gamma$-глобулінові фракції білка майже не змінювалися. Необхідно зазначити, що відносний вміст альбумінів та $\alpha$-глобулінів зростав, а глобулінів, $\beta$ - та $\gamma$-глобулінів - знижувався, проте, у жодному випадку ці зміни не були достовірними. Альбуміново-глобуліновий коефіцієнт збільшився на 0,18 $(\mathrm{P}<0,05)$.

Кращий лікувальний ефект мало одночасне введення інвазованим рибам препарату «Бровермектингранулят $^{\mathrm{TM}} »$ та імуномодулятора «Авесстим ${ }^{\mathrm{TM}} »$.

Про це свідчить значне збільшення вмісту загального білка (на 9,97 г/л $(\mathrm{P}<0,001)$ ), альбумінів (на 8,17 г/л (P < 0,001)), глобулінів (на 1,80 г/л $(\mathrm{P}<0,001)), \alpha$-глобулінів (на 2,20 г/л $(\mathrm{P}<0,001))$ та альбуміново-глобулінового коефіцієнта (на 0,37 $(\mathrm{P}<0,001))$ та несуттєве зменшення $\beta$ - і $\gamma$-глобулінів. Відносний вміст альбумінів порівняно 3 контролем достовірно (P $<0,01)$ зріс на $5,73 \%$, а глобулінів відповідно зменшився на таку ж величину. Відмічалося достовірне $(\mathrm{P}<0,05)$ зростання також відносного вмісту $\alpha$-глобулінів (на $6,13 \%$ ), а відносний вміст $\beta$ - і $\gamma$-глобулінових фракцій несуттєво знижувався.

\section{Висновки}

Застосування препарату «Бровермектингранулят $^{\mathrm{TM}} \gg$ та імуномодулятора «Авесстим ${ }^{\mathrm{TM}} »$ за моногеноїдозів у однорічок білого амура сприяло активації білкового обміну в організмі риб, на що вказує зростання у їх сироватці крові вмісту загального білка, альбумінів, глобулінів та $\alpha$-глобулінів. Кращу нормалізуючу дію на організм уражених ектопарази- тами риб справляло сукупне застосування цих препаратів: вміст у сироватці крові загального білка, залежно від виду інвазії, збільшився на 5,22-9,97, альбумінів - на 4,34-8,17, глобулінів - на 0,88-1,45, $\alpha$ глобулінів на - 1,36-2,20 г\л, причому, ці зміни у всіх випадках (виняток - вміст глобуліну у крові риб, уражених гіродактилюсами) були вірогідними (P $<0,05-$ 0,001).

\section{Бібліографічні посилання.}

Kondrahin, I. P., Kurilova, N.V., Malahov, A.G. (1985). Klinicheskaja laboratornaja diagnostika $\mathrm{v}$ veterinari: spravochnoe izdanie. M.: Agropromizdat (in Russian).

Osoba, I.A., Hrytsyniak, I.I., Basalkevych, Ye.Ye., Pirus, R.I. (2011). Kontsentratsiia bilka ta spivvidnoshennia okremykh bilkovykh fraktsii u syrovattsi krovi odnorichok koropiv riznoho genezu. Naukovotekhnichnyi biuleten Instytutu biolohii tvaryn $\mathrm{i}$ DNDKI vetpreparativ ta kormovykh dobavok. 12(1, 2), 53-56 (in Ukrainian).

Lakin, G.F. (1990). Biometrija. M.:Vysshaja shkola (in Russian).

Loboiko, Yu.V., Berezovskyi, A.V., Stybel, V.V. (2011). Efektyvnist zastosuvannia Brovermektyn-hranuliatutm za lerneoznoi invazii koropa ta yoho vplyv na hematolohichni pokaznyky ryb. Veterynarna medytsyna. 95, 366-367 (in Ukrainian).

Mauer, G. (1971). Disk-elektroforez. Teorija i praktika jelektroforeza v poliakrilamidnom gele. Moskva: Mir (in Russian).

Hrubinko, V.V., Kurant, V.Z., Khomenchuk, V.O. (2010). Osoblyvosti bilkovoho skladu plazmy krovi khrebetnykh: evoliutsiino-ekolohichnyi aspekt. Biolohiia tvaryn. 12(1), 64-67 (in Ukrainian).

Стаття надійшла до редакиї̈ 16.02.2017 